\title{
The Contribution of the International Court of Justice to International Humanitarian Law
}

\author{
Judith Gardam*
}

Keywords: International Court of Justice; international humanitarian law; ius in bello; ius ad bellum.

\begin{abstract}
This article considers the contribution of the International Court of Justice ('ICJ') to the development of the rules and principles of international humanitarian law ('IHL'). In recent times, the contribution of the Court to this body of the law has been overshadowed by the work of the two ad hoc international criminal tribunals, the ICTY and the ICTR, established by the Security Council to punish those responsible for serious breaches of IHL. Nevertheless, the ICJ, in both its contentious and advisory jurisdictions, has considered the provisions of IHL on a number of occasions, and in the process has clarified many areas of IHL. This article is concerned with one particular issue: how does the Court perceive the fundamental nature of IHL? The analysis adopts two themes. First, an assessment is made of the part played by the Court in the process of bringing IHL into conformity with the changing emphasis of general international law. In both the Nicaragua case and the Nuclear Weapons Advisory Opinion the Court continued the process of what has been referred to as the "humanization of international law." Second, the approach of the Court to the vexed issue of the relationship between ius ad bellum and IHL is considered. The conclusion is reached that the approach of the Court to this latter issue has undermined its contribution to infusing the humanitarian ethos into IHL.
\end{abstract}

\section{INTRODUCTION}

In considering the significance of judicial decisions in the context of the norms of international humanitarian law (hereinafter 'IHL'), perhaps it would not be the jurisprudence of the International Court of Justice that would first come to mind. The focus of such an investigation could as readily be the work of the two ad hoc criminal tribunals for the former Yugoslavia ${ }^{1}$ and Rwanda. ${ }^{2}$ Indeed the decisions of the Tribunals have contributed a great deal to the interpretation and development of IHL and international criminal law generally. ${ }^{3}$ The International Criminal Court, with its jurisdiction over war crimes, also has the potential to contribute

* Reader, School of Law, University of Adelaide.

1. The International Criminal Tribunal for the former Yugoslavia was established by the UN Security Council pursuant to S/RES/808 (Febuary 1993) and S/RES/827 (May 1993).

2. The International Criminal Tribunal for Rwanda was established by the UN Security Council pursuant to S/RES/955 (November 1994).

3. See, e.g., T. Meron, War Crimes Law Comes of Age, 92 AJIL 462 (1998); and T. Meron, The Continuing Role of Custom in the Formation of International Humanitarian Law, 90 AJIL 238 (1996).

14 Leiden Journal of International Law 349-365 (2001)

(c) 2001 Kluwer Law International 
in this area. ${ }^{4}$ Moreover, any comprehensive retrospective consideration of the judicial contribution to IHL, would encompass the work of other international and national judicial bodies over a considerable period of time. ${ }^{5}$ Nevertheless, the International Court of Justice, in both its contentious and advisory jurisdictions, has considered the provisions of IHL on a number of occasions. ${ }^{6}$

The jurisprudence of the Court generally involving IHL has had a farreaching impact in clarifying the detail of such diverse matters as the customary status of the four 1949 Geneva Conventions, ${ }^{7}$ the requirements of common Articles 1 and 3 of the Conventions, ${ }^{8}$ and the existence of norms of customary law in non-international armed conflicts. ${ }^{9}$

Of particular significance in hindsight is the development by the Court in the Nicaragua case of a distinctive manner of approaching the requirements of state practice in the formation of customary norms of IHL. The fact that there is such a wide discrepancy between the humanitarian aspirations voiced by governments and the reality of the battlefield, particularly in internal conflicts, undermines the development of customary norms of IHL. ${ }^{10}$ The Court's emphasis in that case on the role of opinio juris in the formation of norms of customary international law and,

4. See the Rome Statute of the International Criminal Court, UN Doc. A/Conf.183/9 (17 July 1998). The Statute was adopted by the United Nations Diplomatic Conference of Plenipotentiaries on the Establishment of an International Criminal Court on 17 July 1998. Art. 5(1)(c) of the Statute includes "war crimes" within the jurisdiction of the Court.

5. See, generally, C. Bassiouni (Ed.), International Criminal Law Volume III Enforcement (1999).

6. See, Military and Paramilitary Activities in and against Nicaragua (Nicaragua v. US), Merits, Judgment, 1986 ICJ Rep. 14 (hereinafter 'the Nicaragua case'); Legality of the Threat or Use of Nuclear Weapons (General Assembly), Advisory Opinion, 1996 ICJ Rep. 26 (hereinafter 'the Nuclear Weapons Advisory Opinion'). The crime of genocide can be constituted by events that occur during armed conflict and is increasingly treated under the rubric of IHL; see Application of the Convention on the Prevention and Punishment of the Crime of Genocide (Bosnia \& Herzegovina $v$. Yugoslavia (Serbia and Montenegro)), 1993 ICJ Rep. 3. In this case, the applicant also alleged breaches of the four 1949 Geneva Conventions, see infra note 7, and customary international law. The Court found its jurisdiction limited to the Genocide Convention, id., at 14. See also Case Concerning Trial of Pakistani Prisoners of War (Pakistan v. India), 1973 ICJ Rep. 328.

7. Geneva Convention for the amelioration of the Condition of the Wounded and Sick in Armed Forces in the Field, 12 August 1949 (75 UNTS 31); Geneva Convention for the Amelioration of the Condition of the Wounded, Sick and Shipwrecked Members of Armed Forces at Sea of 12 August 1949 (75 UNTS 85); Geneva Convention Relative to the Protection of Prisoners of War, 12 August 1949 (75 UNTS 135); and Geneva Convention Relative to the Protection of Civilian Persons in Time of War of 12 August 1949 (75 UNTS 287). On the customary status of the Geneva Conventions, see the Nicaragua case, supra note 6, and the Nuclear Weapons Advisory Opinion, supra note 6.

8. See the Nicaragua case, supra note 6, at 113-115, paras. 218-220. The judgment of the Court in the Nicaragua case, on the customary status of common Arts. 1-3 to the Geneva Conventions, was cited with approval in Prosecutor $v$. Tadić, Case No. IT-94-1-AR 72, Appeal on Jurisdiction (2 October 1995), reprinted in 35 ILM 32, at 55, paras. 93 and 98 (1996).

9. See the Nicaragua case, id.

10. See T. Meron, The Humanization of Humanitarian Law, 94 AJIL 239, at 244 (2000). 
moreover, its acceptance of what states say as supplying both opinio juris and state practice, allows for more scope for the development of customary norms of IHL. Although controversial at the time, this manner of dealing with the formation of custom is a trend that has continued in subsequent developments in IHL and one that has gone from strength to strength in the work of the two ad hoc tribunals. ${ }^{11}$

In contrast, it may be that the Nuclear Weapons Advisory Opinion, the only instance in which IHL played a central role in the issues before the Court, will be considered in retrospect to represent a lost opportunity. What the Court failed to do, as Judge Higgins points out in her Dissenting Opinion, was to "explain, elaborate and apply the key elements of humanitarian law."12 IHL, in common with many other areas of international law, is characterised by broad aspirational principles, the detailed application of which is by no means a straightforward task.$^{13}$ Some of the Dissenting Opinions in the Nuclear Weapons Advisory Opinion, however, compensate for this deficiency of the majority and provide some much needed guidance as to the actual application of the relevant norms of IHL. ${ }^{14}$

Much has been written on the contribution of the Court over the years to various aspects of IHL. ${ }^{15}$ In my view, the issue of most importance in the jurisprudence of the Court on IHL is their perception as to its fundamental nature. How the Court regards the role of IHL determines to a large extent their decisions on the scope and operation of its specific rules in particular cases. This question is the focus of the discussion that follows. There are two aspects to such an inquiry. First, I argue that the Court, although recently confirming the lex specialis nature of IHL and its priority in times of armed conflict over other areas of international law, such as human rights law and environmental law, has contributed to the process of bringing IHL into conformity with the changing emphasis of general

11. See, e.g., Meron, id., at 276. The two ad hoc Tribunals for the former Yugoslavia and Rwanda have been at the forefront of developments in this area, particularly in the context of the criminalisation of events occurring in non-international armed conflicts. See, e.g., T. Meron, International Criminalization of Internal Atrocities, 89 AJIL 554 (1995).

12. Dissenting Opinion of Judge Higgins in the Nuclear Weapons Advisory Opinion, supra note 6 , at 584, para. 10.

13. An example of this phenomenon is the fundamental maxim on which the whole of IHL is based, namely, that the only legitimate object in warfare is to weaken the military strength of the enemy. From this maxim follows the further cardinal principle of the system that the choice of means and methods of attacking the enemy is not unlimited.

14. In particular, see the Dissenting Opinions of Judges Higgins, Shahabuddeen, and Weeramantry. For an analysis of the Court's contribution to the interpretation of the rules of IHL, see L. Doswald-Beck, International Humanitarian Law and the Advisory Opinion of the International Court of Justice on the Legality of the Threat or Use of Nuclear Weapons, 316 Int'l Review of the Red Cross 35 (1997).

15. See, e.g., T. Meron, The Geneva Conventions as Customary Law, 81 AJIL 349, at 351-358 (1987); S. Schwebel, The Roles of the Security Council and the International Court of Justice in the Application of International Humanitarian Law, 27 NYU J Int'1 L \& Politics 731, at 733-746 (1995) and 316 Int'l Review of the Red Cross (1997) (special issue devoted to The Advisory Opinion of the International Court of Justice on the Legality of Nuclear Weapons and International Humanitarian Law). 
international law. In particular, in both the Nicaragua case and the Nuclear Weapons Advisory Opinion, the Court has continued the process referred to by Theodor Meron as the 'humanization' of IHL. ${ }^{16}$ In the Nicaragua case, the Court undertook this process in the context of the 'Law of Geneva,' that part of IHL "which protects the victims of war and aims to provide safeguards for disabled armed forces personnel and persons not taking part in the hostilities." 17 The humanitarian ethos of the rules of IHL that deal with "the rights and duties of belligerents in their conduct of operations and limit[s] the choice of methods and means of injuring the enemy in an international armed conflict," 18 otherwise known as 'Law of the Hague,' was the focus of the decision of the Court in the Nuclear Weapons Advisory Opinion.

Since the adoption of the United Nations Charter, the nature of IHL has been undergoing a subtle but pervasive change. The name IHL is recently coined for what was previously known as the law of war, the underlying rationale of which was anything but humanitarian in nature. ${ }^{19}$ However, in more recent times this regime, initially primarily utilitarian in nature, is now frequently seen as allied, or even as part of, the developing regime of human rights. The nature of the relationship that is alleged to exist between the two regimes varies depending on the context, but the trend is well developed to treat IHL and human rights as sharing common values and as directed to the same ends. ${ }^{20}$ In both the Nicaragua case and the Nuclear Weapons Advisory Opinion, the Court has made a distinctive contribution to this evolving relationship.

There are limits, however, to this process of harmonisation of IHL and human rights and these are illustrated by the second aspect of the Court's perception of the fundamental nature of IHL that I consider in this article. Specifically, the Court in the Nuclear Weapons Advisory Opinion, confronted the vexed issue of the relationship between ius ad bellum and ius in bello or IHL. Ius ad bellum regulates the legality of a state's resort to force, and continues to some extent to be relevant during the period of hostilities. ${ }^{21}$ Once armed conflict has broke out, IHL regulates its conduct for the benefit of all participants irrespective of the illegality of the initial resort to force. Thus there is the paradoxical situation of the law regulating an activity that is itself unlawful.

16. See Meron, supra note 10.

17. See the Nuclear Weapons Advisory Opinion, supra note 6, at 256, para. 75 .

18. Id.

19. See, e.g., C. Jochnick \& R. Normand, The Legitimation of Violence: A Critical History of the Laws of War, 35 HILJ 49, at 58 (1994).

20. See, e.g., R. Vinuesa, Interface, Correspondence and Convergence of Human Rights and International Humanitarian Law, 1998 YIHL 69 (1999).

21. See J. Gardam, Proportionality and Necessity in jus ad bellum and jus in bello, in L. Boisson de Chazournes \& P. Sands (Eds.), International Law, The International Court of Justice and Nuclear Weapons 275, at 280 (1999); and C. Greenwood, Jus ad bellum and jus in bello in the Nuclear Weapons Advisory Opinion, in L. Boisson de Chazournes \& P. Sands (Eds.), Id., 247, at 258 . 
The two regimes, ius ad bellum and IHL, are envisaged as complementary and as working in harmony with one another. As long as the underlying rationale of these two sets of norms is compatible, the potential for conflict is minimal. However, I argue that the movement of IHL towards a more "humanitarian" role does not always sit easily with the continued dominance in ius ad bellum of considerations relating to military victory and the survival of the state.

\section{The Underlying Nature of IHL}

Increasingly, there is a perception that not only do IHL and human rights law share a common underlying philosophy but that human rights norms can compensate for the deficiencies of IHL. Human rights norms, however, currently can achieve only so much in times of armed conflict. They are designed to operate during times of peace and regulate the relations between a state and its own citizens. ${ }^{22}$ They can and do supplement IHL, particularly during times of non-international armed conflict. ${ }^{23}$ However, the issues with which these norms deal take on new forms in the midst of the disruption caused by armed conflict, a factor that is not necessarily reflected in their content. Moreover, even in the context of non-international armed conflicts where they have more to offer, human rights norms do not bind non-state actors, and except for a basic core of rights, human rights norms can be derogated from during armed conflict. ${ }^{24}$ IHL is thus of primary importance in so many situations of violence that occur in today's world.

It is commonplace to find modern IHL described as a compromise between humanitarian concerns and military necessity, with the suggestion that nowadays the influence of humanity predominates. ${ }^{25}$ The influence of humanitarian considerations on IHL first grew out of the humanitarianism movement of the nineteenth century. Their impact can be seen in such law of war documents as the Lieber $\operatorname{Code}^{26}$ and the Martens

22. See C. Greenwood, Scope of Application of Humanitarian Law, in D. Fleck (Ed.), The Handbook of Humanitarian Law in Armed Conflicts 102 (1995).

23. See T. Meron, Human Rights in Internal Strife: Their International Protection 2-70 (1987).

24. The non-derogable human rights include the right to life; freedom from torture and other inhuman or degrading treatment or punishment; freedom from slavery; and the nonretroactivity of penal laws. See Vinuesa, supra note 20, at 87-90 (for a discussion of nonderogable human rights).

25. This tendency is particularly marked in the publications of the International Committee of the Red Cross (hereinafter 'ICRC'). For a general discussion of humanitarianism in the law of armed conflict, see H. McCoubrey, International Humanitarian Law 40 (1998); Meron, supra note 10; and see also C. Greenwood, Historical Development and Legal Basis, in Fleck, supra note 22, at 129-133.

26. See, e.g., Arts. 43 and 47 of US War Department Instructions for the Government of Armies of the United States in the Field, General Orders No. 100 (24 April 1863); and see T. Meron, Francis Lieber Code and Principles of Humanity, 32 CJTL 269 (1978-1998). 
Clause in the Preamble to the 1907 Hague Convention on the Laws and Customs of War on Land, the latter instrument specifically referring to the "laws of humanity." 27 Today, this influence is represented by the regime of human rights. ${ }^{28}$ The development in the last fifty years of the principles that comprise human rights law has had a major influence on IHL, and indeed on international law generally. The United Nations Charter, with its background of the 'scourge' of World War II and its emphasis on the protection of the individual, led to the growing convergence between these regimes. Moreover, the Charter ban on the use of force led to a perception that for states to continue to emphasise the development of rules regulating hostilities seemed somewhat too cynical in light of the illegality of war. Concentrating on the humanitarian component of the rules, however, reflected the growth in weapons of mass destruction and the emerging concern with human rights. The 1968 Conference on Human Rights in Tehran can be seen as the definitive event in the emerging relationship between IHL and human rights. ${ }^{29}$ Gerald Draper wrote that progress in the law of armed conflict "had come perilously close to stagnation before the impact of the movement for a regime of Human Rights was brought to bear." 30

The growing emphasis in international law on the protection of the individual found its practical expression in IHL in the two 1977 Additional Protocols to the four 1949 Geneva Conventions. ${ }^{31}$ Protocol I, dealing with international armed conflicts, contains the first comprehensive conventional protections for the civilian population against the effect of hostilities. These new rules represent a major inroad of humanitarian considerations into the Law of The Hague. The effective protection of civilians in modern day armed conflict is dependent on the regulation of the actual conduct of warfare, not just its aftermath, and the achievement of Protocol I in this respect is considerable.

There reaches a stage, however, where the influence of humanitarian values in IHL inevitably must confront the realities of the military considerations that are so significant in this area of the law. A fundamental distinction between the regimes of human rights and IHL, an apprecia-

27. See Convention [No. IV] Respecting the Laws and Customs of War on Land, with annex of regulations, 18 October 1907, 36 Stat. 2277, 1 Bevans 631.

28. For the influence of human rights on IHL generally and the developing relationship between the two regimes, see Meron, supra note 23; and Vinuesa, supra note 20. See also the Dissenting Opinion of Judge Weeramantry in the Nuclear Weapons Advisory Opinion, supra note 6 , at 260-269.

29. See Res. XXIII, Human Rights in Armed Conflict, adopted by the International Conference on Human Rights, Teheran, 12 May 1968.

30. G. Draper, Human Rights and the Law of War, 12 VJIL 326, at 336 (1972).

31. Protocol Additional to the Geneva Conventions of 12 August 1949, and relating to the Protection of Victims of International Armed Conflicts, adopted in 1977 (Protocol I), 1125 UNTS 3-608 (1979) and Protocol Additional to the Geneva Conventions of 12 August 1949, and relating to the Protection of Victims of non-international Armed Conflicts, adopted in 1977 (Protocol II), 1125 UNTS 609-699 (1979). 
tion of which is crucial to understanding the limitations of humanity in IHL, is the traditional role and continued influence of the military in the origins and development of IHL. In contrast to human rights law, the focus of which has been on conferring rights on individuals to protect them from arbitrary actions by the state, IHL traditionally has primarily conferred rights on states that are designed to further military efficiency. ${ }^{32}$ Thus, although the term IHL is the preferred term of the International Committee of the Red Cross to describe the law of armed conflict, it is misleading to the extent that it conveys an impression that these rules are based on purely humanitarian considerations. ${ }^{33}$ In fact, traditionally the rules have been based on the advantages in efficiency that states perceive as flowing from the regulation of warfare. Some writers have gone as far as to claim that "the laws of war have been formulated deliberately to privilege military necessity at the cost of humanitarian values." ${ }^{34}$ Others recognise that

[b]y war's very nature, the practices that become effective (rather than aspirational) law will be influenced decisively by the concerns of military specialists to protect their own personnel and assets and to use them effectively. ${ }^{35}$

Set against this background, the approach of the Court to IHL, in both the Nicaragua case and the Nuclear Weapons Advisory Opinion, reflects a trend that has been apparent since the adoption of the United Nations Charter and continues the process of promoting the idea of humanity as the underlying rationale of IHL. How was this result achieved?

In the Nicaragua case the Court developed the category of what it referred to as the "fundamental general principles of humanitarian law." 36 This was not the first time that the idea of basic considerations of humanity in the context of force had been articulated by the Court. In the Corfu Channel case the Court regarded the failure of Albania to notify shipping of the existence of mines in its territorial waters as inconsistent with what it referred to as "certain general and well-recognised principles, namely: elementary considerations of humanity, even more exacting in peace than in war." 37 This idea was further developed by the Court in the Nicaragua case, where the view was expressed that the four 1949 Geneva Conventions were "in some respects a development, and in other respects no more than

32. See Jochnick \& Normand, supra note 19. Cf. Meron, supra note 10, at 251 (describing the rights conferred on individuals by IHL).

33. See L. Doswald-Beck \& S. Vite, International Humanitarian Law and Human Rights Law, 293 IRRC 94, at 98 (1993), who write that this is one reason for the preference of writers for the term the law of armed conflict, or the law of war, rather than humanitarian law.

34. Jochnick \& Normand, supra note 19 , at 50.

35. W. Reisman \& C. Antoniou, The Laws of War: A Comprehensive Collection of Primary Documents on International Laws Governing Armed Conflict xxv (1994).

36. See the Nicaragua case, supra note 6, at 113, para. 218.

37. Corfu Channel case (UK v. Albania), Merits, 1949 ICJ Rep. 4. 
an expression, of such principles." ${ }^{38}$ From these fundamental principles came a certain core of rules applicable in both international and noninternational armed conflicts that reflected "elementary considerations of humanity," and these were to be found in common Article 3 to the Geneva Conventions. ${ }^{39}$ Moreover, parties were obliged, pursuant to common Article 1 to the Geneva Conventions, "to respect and ensure respect' for these fundamental general principles of humanitarian law."

The assumption by the Court of the humanitarian ideal underlying much of IHL was uncontroversial. However, their assessment of common Article 3 to the four 1949 Geneva Conventions as constituting core principles of IHL across both international and non-international armed conflict, as a matter of customary international law, has been criticised. ${ }^{41}$ It was always debatable whether the norms of common Article 3 in fact encapsulate the core principles of the four 1949 Geneva Conventions. ${ }^{42}$

In light of the facts of the case, the Court's catalogue of humanitarian principles in the Nicaragua case was confined to Geneva law. ${ }^{43}$ The issue before the Court in the Nuclear Weapons Advisory Opinion, however, provided an opportunity for an in-depth analysis of the regime of IHL in the context of the means and methods of warfare in international armed conflicts. ${ }^{44}$ Moreover, an assessment of the fundamental nature of IHL lies at the very heart of the decision. The judgments generally assume the importance, and in some cases, the dominance of humanitarian considerations in IHL and those of a military nature are relegated to the background. This result of course is made easier for many members of the Court by their analysis of the importance of military considerations in ius ad bellum combined with the "Armageddon" potential of nuclear weapons.

The Advisory Opinion also represents a welcome development in the explicit extension of the humanitarian ideal of IHL to combatants. Commentators have lamented the difficulty of achieving any progress in improving the protections offered by IHL to combatants. ${ }^{45}$ Previously, the changing emphasis in IHL so as to more reflect the demands of humanity had taken place almost exclusively in the context of the protections

38. Id., see R. Abi-Saab, The General Principles of Humanitarian Law According to the International Court of Justice, 259 Int'l Review of the Red Cross 367 (1987).

39. Nicaragua case, supra note 6 , at 114 , para. 219.

40. Id., at para. 220 .

41. See Meron, supra note 15 , at 351-358.

42. Id., at 356-357.

43. The Court, however, did find that the laying of mines in Nicaraguan waters was illegal as contrary to elementary considerations of humanity. Nicaragua case, supra note 6 , at 112 , para. 215.

44. The definition of the Law of The Hague adopted by the Court is limited to international armed conflicts, see supra note 17.

45. For the difficulties in persuading the military and states generally to accept improvements in the protections offered to combatants, see L. Doswald-Beck, Obstacles to Regulating New Weaponry: Battlefield Laser Weapons, in H. Fox \& M. Meyer (Eds.), Effecting Compliance, Armed Conflict and the New Law 107 (1993). 
available to civilians. ${ }^{46}$ This process was continued in the Nicaragua case, where the Court developed "elementary considerations of humanity" in the context of protection for civilians. Therefore, the acknowledgment in the Opinion of the relevance of the humanitarian ideal to combatants, provides important support for efforts to improve the protection they receive from IHL.

In the Nuclear Weapons Advisory Opinion the Court isolates what it considers to be the "cardinal principles of humanitarian law" that are of an "intrinsically humanitarian character." ${ }^{47}$ In the view of the Court, the humanitarian character of IHL "permeates the entire law of armed conflict and applies to all forms of warfare and to all kinds of weapons, those of the past, those of the present and those of the future." 48 These principles constituting the fabric of humanitarian law are as follows:

The first is aimed at the protection of the civilian population and civilian objects and establishes the distinction between combatants and non-combatants; States must never make civilians the object of attack and must consequently never use weapons that are incapable of distinguishing between civilian and military targets. According to the second principle, it is prohibited to cause unnecessary suffering to combatants: it is accordingly prohibited to use weapons causing them such harm or uselessly aggravating their suffering. In application of that second principle, States do not have unlimited freedom of choice in the weapons they use. ${ }^{49}$

Moreover, the Court expressed the view that the fundamental rules of IHL constitute "intransgressible principles of international customary law." ${ }^{50} \mathrm{It}$ is unclear exactly what this expression signifies. It could be that the Court is thinking here in terms of jus cogens norms, were it not for the fact that they expressly excluded from their analysis a consideration of the status of the norms of IHL. ${ }^{51}$

Judge Higgins, in her Dissenting Opinion, also affirms the underlying humanitarian rationale of IHL. ${ }^{52}$ Importantly, she indicates that this humanitarian rationale should be a consideration in resolving the respective demands of ius in bello and ius ad bellum:

[t]he judicial lodestar, whether in difficult questions of interpretation of humanitarian law, or in resolving claimed tensions between competing norms, must be

46. $C f$., however, Protocol on Blinding Laser Weapons (Protocol IV to the United Nations Convention on Prohibitions or Restrictions on the Use of Certain Conventional Weapons Which May be Deemed to be Excessively Injurious or to Have Indiscriminate Effects), 13 October 1995.

47. Nuclear Weapons Advisory Opinion, supra note 6, at 257, para. 78.

48. Id., at 259 , para. 86 .

49. $I d$., at 257 , para. 78

50. Id., at para. 79 .

51. Id., at 258, para. 83. Some of the other members of the Court discussed the status of the norms of IHL and found that they represented norms of jus cogens, see, e.g., the Dissenting Opinion of Judge Weeramantry, id., at 496.

52. Id., at 584, paras. $9-10$. 
those values that international law seeks to promote and protect. In the present case, it is the physical survival of peoples that we must constantly have in view. ${ }^{53}$

A further consideration of the scope of the humanitarian nature of IHL occurred in the context of consideration of the so-called Martens Clause, that specifically refers to the constraints of "the laws of humanity." As originally formulated in the Preamble to the Hague Convention on the Laws and Customs of War on Land, the Martens Clause read:

Until a more complete code of the laws of war is issued, the High Contracting Parties think it right to declare that in cases not included in the Regulations adopted by them, populations and belligerents remain under the protection and empire of the principles of international law, as they result from the usages established between civilized nations, from the laws of humanity, and the requirements of the public conscience.

The Clause has been re-iterated in slightly different form in various conventional documents and the phrase 'laws of humanity' is now more commonly known as 'principles of humanity.' ${ }^{54}$ The exact significance of the Clause has never been clearly established..$^{55}$ There are a variety of views. ${ }^{56}$ The question before the Court was whether the Clause adds anything substantive to the Court's articulation of the cardinal principles constituting the fabric of humanitarian law. For example, can the requirement of the 'public conscience' outlaw the use of a particular weapon which may not otherwise infringe the prohibition on unnecessary suffering or indiscriminate collateral casualties? A radical view of the requirements of the Clause was presented by parties to the Court. ${ }^{57}$ It was argued that the dictates of the public conscience could have the effect of outlawing a means of warfare, irrespective of state consent thereto through the development of traditional norms of customary or conventional law. Thus, it was argued, the Clause was a means by which IHL could keep in step with new developments in community values that were not necessarily reflected in the opinio juris of states. ${ }^{5}$

No real guidance is provided by the Court as to the scope of the Martens

53. Id., at 592, para. 41 .

54. For a discussion of the origins of the Martens Clause and its significance in modern IHL, see T. Meron, The Martens Clause, Principles of Humanity, and Dictates of Public Conscience, 94 AJIL 78, at 79 (2000); and A. Cassese, The Martens Clause: Half a Loaf or Simply Pie in the Sky?, 11 EJIL 187 (2000).

55. For an explanation of the varying views on the scope of the Martens Clause in modern IHL, see R. Ticehurst, The Martens Clause and the Laws of Armed Conflict, 317 Int'1 Review of the Red Cross 125, at 126 (1997).

56. E.g., the Russian Federation in its pleadings before the Court in the Nuclear Weapons Advisory Opinion, expressed the view that the Martens Clause was obsolete due to the now codified nature of IHL, cited in Ticehurst, supra note 55, at 127.

57. See, e.g., the submission to the Court by the Solomon Islands.

58. See, e.g., the statement of Australia's Minister for Foreign Affairs to this effect, extracted in J. Burroughs, The (Il)legality of Threat or Use of Nuclear Weapons 100 (1997). 
Clause. In referring to the Clause in relation to the cardinal principles of humanitarian law, the Court confines itself to the statement that it "has proved to be an effective means of addressing the rapid evolution of technology." ${ }^{59}$ It seems that the assessment by Judge Cassese that the Court does nothing to clarify the actual requirements of the Martens Clause is correct, and it is left to the realm of conjecture what was intended. ${ }^{60}$

In contrast, the Dissenting Opinion of Judge Shahabuddeen provides a comprehensive analysis of the place of the Martens Clause in modern IHL and confers on it a wide operation. ${ }^{61}$ In his view its requirements, particularly those relating to the public conscience, are not merely rhetorical but confer substantive rights on individuals over and above those provided by the detail of the customary and conventional rules. The clause "provided authority for treating the principles of humanity and the dictates of public conscience as principles of international law, leaving the precise content of the standard implied by these principles of international law to be ascertained in the light of changing circumstances." ${ }^{62}$ Moreover, "the views of States were relevant only for their value in indicating the state of the public conscience, not for the purpose of determining whether an opinio iuris exists [...]." ${ }^{\prime 3}$

Despite a degree of equivocation over the detail, the predominance of the demands of humanity in the conduct of armed conflict, therefore, has unequivocally received the imprimatur of the International Court of Justice. It remains to investigate how the Court has approached the two characteristics of international law that are continuing obstacles to the process of harmonisation of IHL with "the values that international law seeks to protect," namely, the lex specialis nature of IHL and its relationship with ius ad bellum.

\section{The Relationship Between IHL ANd Other Norms OF INTERNATIONAL LAW}

\subsection{The lex specialis nature of IHL}

IHL has not been static in light of developments in general international law. Specifically it has re-acted to the growing emphasis on the protec-

59. Nuclear Weapons Advisory Opinion, supra note 6, at 257, para. 78. For a discussion of the history and scope of the Martens Clause and its treatment by members of the Court in the Nuclear Weapons Advisory Opinion, see Meron, supra note 54.

60. See Cassese, supra note 54.

61. See the Dissenting Opinion of Justice Shahabuddeen in the Nuclear Weapons Advisory Opinion, supra note 6, at 405-411; and see also Dissenting Opinion of Judge Weeramantry in the Nuclear Weapons Advisory Opinion, id., at 486-490.

62. Dissenting Opinion of Justice Shahabuddeen in the Nuclear Weapons Advisory Opinion, supra note 6 , at 406 .

63. Id., at 410 . 
tion of human rights (and the environment), as reflected in the development of legal norms, by adopting rules that recognize the importance of these values to the international community. ${ }^{64}$ Despite these advances in IHL, however, there is the perception in some quarters that IHL just cannot move fast enough to meet the increasing demands that the impact of armed conflict on civilians be effectively addressed. This view is reflected in some of the arguments presented to the Court in the Nuclear Weapons Advisory Opinion, the first time that the Court has been called upon to explicitly deal with the relationship between IHL, human rights law, and environmental law. In effect what some states were seeking in the Nuclear Weapons Advisory Opinion was for the Court to address the issue of the supremacy of IHL in the context of armed conflict. The accepted view is that when armed conflict breaks out it is the lex specialis of IHL that becomes operative and the general norms of international law are in abeyance.

In relation to human rights norms, the particular context in which the Court was asked to re-think the issue of boundaries was in relation to the right to life under Article 6 of the Covenant on Civil and Political Rights. Several states argued that the use of nuclear weapons was inconsistent with this right. Traditionally the scope of the right to life during times of armed conflict is governed by the requirements of IHL that delimit what is a lawful taking of life, for example, the rules on indiscriminate attacks that determine the scope of legitimate collateral civilian casualties. The Court affirmed the limits on the right conferred by Article 6 of the Covenant, refusing to take up the opportunity to re-think the lex specialis nature of IHL and its dominant role in regulating armed conflict. Clearly the Court supported the view that it was appropriate for developments that emphasized the changing values of the international community to take place within established legal boundaries. However, the Court did confirm the relevance of other compatible human rights norms in the Covenant in times of armed conflict, a finding that continues the process of bringing the two regimes into closer harmony ${ }^{65}$ Having affirmed the predominant role of IHL in relation to other norms of international law in regulating the conduct of armed conflict, the Court then moved on to consider IHL in relation to ius ad bellum.

\subsection{Relationship between ius ad bellum and ius in bello}

The Court in the Nicaragua case, although it dealt comprehensively with many aspects of ius ad bellum, was not confronted with the fact situation where a state's liberty to use force under the principles of ius ad bellum placed it in potential conflict with the requirements of IHL. However, the

64. See the discussion, supra note 31 and accompanying text. In relation to the environment in times of armed conflict, see Arts. 55 and 56 of Protocol I.

65. See Greenwood, supra note 21, at 255-256. 
issue of weapons that was central to the Nuclear Weapons Advisory Opinion, is governed by principles of both ius ad bellum and IHL. The requirements of proportionality in the exercise of self-defence regulates, amongst other things, the choice of weapons that are available to states in exercise of this right. Weapons are also governed by the proportionality equation in IHL, as elaborated in the rules prohibiting indiscriminate attacks and unnecessary suffering. In such a situation the possibility exists that the use of weapons legitimate under ius ad bellum may not meet the proportionality requirements of IHL (and indeed the reverse). The Court in the Nuclear Weapons Advisory Opinion was faced with the situation that if states are at liberty to forcibly defend themselves against attack (the prevailing position under the Charter), can one of their most effective means of doing so be denied to them by IHL? It is difficult to conceive of a situation where the pressure on maintaining the ideal of humanitarianism in IHL could be so extreme. Nuclear weapons are at the very limits of weaponry and seem to be totally at odds with any idea of humanity, a fact clearly appreciated by the Court.

The Court made it clear that theoretically both the requirements of ius ad bellum and IHL must be satisfied: they are cumulative and not alternative. ${ }^{66}$ At one time there was some support for the view that an unlawful aggressor state was not entitled to the benefit of IHL. This approach never gained significant endorsement. Nevertheless the unequivocal rejection of this view by the Court is confirmation of the primarily humanitarian nature of IHL and its applicability to all victims irrespective of the legal position under ius ad bellum. Despite this finding of the apparent equality of IHL the Court then appears to have qualified its position.

There are a variety of ways of conceptualising the decision in the Nuclear Weapons Advisory Opinion on the relationship between ius ad bellum and IHL. Judge Higgins regards the conclusion of the Court as establishing the predominance of the ius ad bellum over IHL: "[t]hrough this formula of non-pronouncement the Court necessarily leaves open the possibility that a use of nuclear weapons contrary to humanitarian law may nevertheless be lawful." ${ }^{67}$ It was the Court's statement that "the use of such weapons seems scarcely reconcilable with such requirements," that led to her conclusion.

For judges Schwebel and Fleischer, the issue was more straightforward, as they found no conflict between the two bodies of rules. In their opinion IHL was compatible in certain circumstances with the use of nuclear weapons in self-defence. Other members of the Court, such as judges Shahabuddeen and Weeramantry, experienced no difficulty in concluding that nuclear weapons would always infringe the requirements of IHL

66. Nuclear Weapons Advisory Opinion, supra note 6, at 245, para. 42.

67. Dissenting Opinion of Judge Higgins in the Nuclear Weapons Advisory Opinion, supra note 6, at 590, para. 29. See also Dissenting Opinion of Judge Shahabuddeen in the Nuclear Weapons Advisory Opinion, id., at 426. 
and the exercise of self-defence had to take place within its limits. Commentators, moreover, take various positions on exactly what the Court actually decided in the case. ${ }^{68}$ There is unanimity, however, as to the unfortunate lack of clarity in the law on an issue so fundamental to respect for international law generally.

How can the question of the relationship between these two areas of the law governing armed conflict be moved forward so as to ensure that the humanitarian ideal of IHL does not have the potential to fail when it is most needed? Unless armed conflict is outlawed there is a continuing need to recognize the legitimate demands of self-defence. However, there are also the growing imperatives of communal values.

An alternative to conceptualising the issue as a conflict between ius ad bellum and IHL, with one or the other prevailing, is to re-think the content of ius ad bellum so as to bring it into closer harmony with IHL. The Nuclear Weapons Advisory Opinion does not challenge the existing perception of ius ad bellum, in particular it does not attempt to give this concept a humanitarian perspective for either combatants or civilians. This could have been achieved by an indication that the requirement that the use of force in self-defence be proportionate, includes a humanitarian component. All the Court contributed to the important question as to the scope of proportionality in ius ad bellum, was to state that the principle "[may] not in itself exclude the use of nuclear weapons in self-defence in all circumstances." ${ }^{69}$ In response to the argument presented to the Court that the very nature of the risks associated with nuclear weapons was inconsistent with compliance with proportionality, the somewhat unhelpful response was that

it suffices for the Court to note the very nature of all nuclear weapons and the profound risks associated therewith are further considerations to be borne in mind by States believing they can exercise a nuclear response in self-defence in accordance with the requirements of proportionality. ${ }^{70}$

It is true that traditionally the proportionality requirement in ius ad bellum has been more concerned with ensuring that states are allowed the minimum that is required to defend themselves against an aggressor than with the suffering of individuals. Excessive destruction of another state in self-defence is seen as having the potential to destabilise a system that is founded on the peaceful settlement of disputes and a collective security system. ${ }^{71}$ Proportionality in ius ad bellum has always focussed on damage

68. See, e.g., Greenwood, supra note 21, at 265; and L. Condorelli, International Humanitarian Law, or the Court's Exploration of a Terra Somewhat Incognito to It, in L. Boisson de Chazournes \& P. Sands (Eds.), International Law, The International Court of Justice and Nuclear Weapons 228 (1999).

69. Nuclear Weapons Advisory Opinion, supra note 6, at 245, para. 42.

70. Id., at para. 43 .

71. See C. Greenwood, Self-Defence and the Conduct of International Armed Conflict, in International Law at a Time of Perplexity 273, at 278 (1989). 
to the enemy state as an abstract entity apart from its individual inhabitants, taking into account such factors as infringement of territorial sovereignty and the general destruction caused to the state and its population. Therefore, although the dual proportionality equation in ius ad bellum and IHL incorporate a consideration of the same general factors, each has its own emphasis. In the context of weapons, the relevant factors when considering whether a particular weapon or its use is a proportionate action in self-defence relate to damage to the civilian population as a whole, the level of destruction of the enemy forces, and finally damage to territory, the infrastructure, and the environment. Under IHL it is the effect of a weapon on civilians and combatants as individuals that requires assessment.

If the Court in the Nuclear Weapons Advisory Opinion had elaborated on the requirements of ius ad bellum and perceived it as having a humanitarian aspect, this may have provided scope for dealing with a recent trend in the methods of warfare adopted by states that is a major factor in the increasing difficulty in achieving effective protections for civilians in modern armed conflict. I am referring here to the practise of states of adopting means and methods of warfare that prioritise the protection of their own combatants but nevertheless gravely endanger the civilian population. For example, aerial bombardment at high-level altitudes may minimise combatant casualties but leads to increased risk of civilian casualties and widespread damage to civilian objects. Once again the rationale for the adoption of such strategies is the survival of the military forces of the state, and hence ultimately the state itself. The prioritizing of combatants' lives in "morally" (if not always legally) justifiable resorts to force can be seen not only in the Persian Gulf conflict (1990-1991) but also the "zero casualties" policy of the NATO forces in the 1999 Kosovo conflict. ${ }^{72}$

The proportionality equation, as it currently stands in IHL, is not designed to deal with the extent to which a military commander must assume a higher level of risks for his/her own combatants in order to protect the civilian population of the opposing side. ${ }^{73}$ It is the proportionality equation in ius ad bellum that is suited to performing this function. Ius ad bellum determines what is proportionate to achieving the overall aim of the use of force and controls the legitimacy of the choice of means and methods of warfare. It appears, however, that a state is at liberty to plan its campaign, including its preferred method of warfare, in order to

72. See A. Rogers, Zero-Casualty Warfare, 837 Int'1 Review of the Red Cross 165 (2000). For the results of this policy on civilians and civilian objects, see Report on the Human Rights Situation Involving Kosovo, submitted by Mary Robinson, High Commissioner for Human Rights, UNHCHR, Geneva, 30 April 1999, and Human Rights Watch Civilian Deaths in the NATO Air Campaign, February 2000.

73. See W. Fenrick, Attacking the Enemy Civilian as a Punishable Offense, 7 Duke JCIL 539, at 548-549 (1997) (highlighting the difficulty in determining the obligations on a commander to expose his/her forces to risk). 
reduce its combatant casualties, without infringing the requirements of ius ad bellum. What is more, an examination of the recent practice of states confirms that proportionality in the context of ius ad bellum primarily serves as a rhetorical tool to support whatever view is taken as to the morality of a particular use of force. ${ }^{74}$ The Court in the Nuclear Weapons Advisory Opinion has done nothing to deter such an approach.

\section{Conclusion}

Sir Hersch Lauterpacht, in his celebrated work on the International Court of Justice and its contribution to international law, wrote that

it would appear that the primary purpose of the International Court [...] lies in its function as one of the instruments for securing peace in so far as this aim can be achieved by law $[\ldots]{ }^{75}$

The work of the Court in relation to IHL cannot be seen as having contributed in any direct sense towards the resolution of actual or potential disputes between states. However, as Sir Hersch acknowledged, the Court can make a less tangible contribution by developing and clarifying the rules and principles of international law. ${ }^{76}$ Any judgment on this basis must be made in relation to opportunity and these have not been frequent for the Court in relation to the regime of IHL.

At the end of the day, as I have suggested in this article, it is not the detail of what the Court actually may have decided on the facts before them that is significant in the context of IHL but the particular view of IHL that the work of the Court has advanced. The process of underlining the importance of the humanitarian ends of IHL started with the Nicaragua case and was considerably developed in the Nuclear Weapons Advisory Opinion. In the Opinion, all members of the Court, even those who were of the view that IHL was compatible with the use of nuclear weapons, clearly indicated the dominance of humanitarian considerations in IHL. To find this endorsement of the role of humanity in the Law of The Hague is indeed progress that may not have been so readily forthcoming if the Advisory Opinion had concerned conventional weapons. The use of conventional weapons in armed conflict does not strain the very notion of

74. $C f$. the conclusions reached as to the legality of the forceful actions of NATO in Kosovo, by C. Chinkin, Kosovo: A Good or Bad War?, 93 AJIL 841, at 844-845 (1999); and M. Reisman, Kosovo's Antinomies, 93 AJIL 860, at 861-862 (1999). Both authors refer to proportionality to support their views. Professor Chinkin, however, transcends rhetoric and provides an analysis of the factors that she regards as part of the proportionality equation that were not satisfied by NATO's response in Kosovo. See also M. Reisman \& D. Stevick, The Applicability of International Law Standards to United Nations Economic Sanctions Programmes, 9 EJIL 86, at 129 (1998).

75. H. Lauterpacht, The Development of International Law by the International Court 3 (1958).

76. $I d$. 
humanity in the way that nuclear weapons do. Therefore, paradoxically the fact that the Court had before it the issue of nuclear weapons may well have contributed to a more comprehensive advancement of the humanitarian ideal of IHL than might otherwise have been the case.

Nevertheless, the perception if not the reality that remains is that IHL is in some way the hand maiden of the ius ad bellum. It is to be hoped that the opportunity may present itself for the Court in the not too distant future to dispel this disquieting appearance and to develop the requirements of ius ad bellum so as to bring it into closer harmony with IHL. 